\title{
PENINGKATAN KARAKTER SISWA MELALUI PEMBELAJARAN IPS TERPADU MODEL NESTED DI SMP NEGERI 3 BANGUNTAPAN BANTUL
}

\author{
Sofli dan Ajat Sudrajat \\ SMP N 1 Pajar Bulan Kabupaten Lahat, Universitas Negeri Yogyakarta \\ sofliale@yahoo.co.id, ajat@uny.ac.id
}

\begin{abstract}
Abstrak
Penelitian ini bertujuan untuk (1) meningkatkan karakter peserta didik melaluipembelajaran IPS terpadu model nested di kelas, (2) meningkatkan keterampilan peserta didik,dan (3) meningkatkan hasil belajar peserta didik melalui pembelajaran IPS terpadu model nested.Subjek penelitian adalah 26 orang peserta didik kelas VII G SMP N 3 Banguntapan, Bantul tahun pembelajaran 2013/2014. Untuk mengungkap karakter menggunakan teknik observasi, angket, dokumentasi dan wawancara. Untuk mengungkap keterampilan menggunakan teknik observasi.Untuk mengungkap hasil belajar menggunakan tes dan dokumentasi.Tindakan yang dilakukan meliputi inkulkasi, permodelan, fasilitasi, dan pengembangan keterampilan. Penggunaan model nested untuk memudahkan pada pendekatan komprehensif dan terintegrasi dalam pembelajaran. Penelitian ini dilaksanakan dalam tiga siklus.Hasil penelitian adalah sebagai berikut. (1)Ada peningkatan karakter peserta didik berdasarkan hasil observasi. Pada siklus I karakter peserta didik 60\%; siklus II 74\%; dan siklus III 83,55\%. Ada peningkatan karakter peserta didik berdasarkan hasil angket. Pada siklus I 83,41; siklus II 84,70; dan siklus III 85,73. (2) Ada peningkatan keterampilan peserta didik pada pembelajaran IPS Terpadu Model Nested. Pada siklus I 56,15; siklus II 68,46; dan siklus III 71,15. (3) Ada peningkatan nilai tes peserta didik pada pembelajaran IPS Terpadu Model Nested. Pada siklus I nilai tes peserta didik 69,60; siklus II 77,69; dan siklus III 76,92.
\end{abstract}

Kata Kunci: karakter, terpadu, model nested, hasil belajar IPS.

\section{IMPROVING STUDENTS' CHARACTERS THROUGH INTEGRATED SOCIAL SCIENCE TEACHING OF NESTED MODEL IN SMP NEGERI 3 BANGUNTAPAN, BANTUL}

\author{
Sofli dan Ajat Sudrajat \\ SMP N 1 Pajar Bulan Kabupaten Lahat, Universitas Negeri Yogyakarta \\ sofliale@yahoo.co.id, ajat@uny.ac.id
}

\begin{abstract}
This study aimed (1) to impove the students' character through integrated social science teaching of the model, (2) to impove the students'skill, and (3) to increasethe students'learning outcome through integrated social science teaching of the model. The subjects were 26 students of class VII G, SMP N 3 Banguntapan in the academic year of 2013/2014. Was used to determine the students' characters, techniques used were observation, questionnaire, documentation, and interview. Was used to determine the students' skill, techniques used were observation. Was used to determine the students' learning outcomes, techniques used were test and observation. Action do with comprise inculcation,modeling, facilitation, and skill building. The nestedmodel used abridge execute comprehensive approach and integrate learning processes. The study consisted of three cycles. The results are as follows. (1) There is an increase in the character of students based on observation. In the first cycle, learners' character is $60 \%$; in cycle II $74 \%$, and in cycle III $83.55 \%$. There is an increase in the character of students based on questionnaire. In the first cycle, the learners character is 83.41; in cycle II 84.70, and in cycle III 85.73. (2) There is an increase in the learning skills of students in integrated social studies of nested model. In the first cycle, the skill is 56.15; in second cycle 68.5, and in the third cycle 71.15. (3) There is an increase in the test scores of the students in learning. In the first cycle students' test score is 69.60; in the second cycle 77.69, and in the third cycle 76.92.
\end{abstract}

Keywords: character, integrated, nested models, learning outcomes IPS. 


\section{Pendahuluan}

Dewasa ini bangsa Indonesia menghadapi berbagai tantangan dalam kehidupan berbangsa dan bernegara. Di antara penyebab tantangan tersebut adalah semakin luntur rasa kebangsaan pada sebagian orang Indonesia, khususnya usia muda.

Di bidang pendidikan, dihadapkan dengan permasalahan baru sebagai akibat dari adanya perkembangan dunia global.Buku Kebijakan Nasional Pembangunan Karakter Bangsa (Puskurbuk, 2010, p2) mencatat, saat ini terjadi kesenjangan sosial ekonomi dan politik, kerusakan lingkungan, pergaulan bebas, dll.Sementara itu budaya bangsa Indonesia santun, pemalu, ihlas, pemaaf, rela berkorban, gotong royong, dan pantang menyerah semakin terkikis. Hal ini terjadi antara lain karena lemahnya mempertahankan budaya bangsa.

Lickona, (Triatmanto, 2010, p201)ada sepuluh perilaku manusia yang menandai kehancuran suatu bangsa yaitu: (1) meningkatnya kekerasan di kalangan remaja,( 2) ketidakjujuran yang membudaya, (3) tingginya rasa tidak hormat kepada orang tua, guru, dan figur pemimpin, (4) pengaruh teman sebaya terhadap perilaku kekerasan, (5) peningkatnya kecurigaan dan kebencian, (6) penggunaan bahasa yang memburuk, (7) penurunan etos kerja, (8) menurunnya rasa tanggungjawab individu dan warga negara, (9) meningginya perilaku merusak diri, dan (10) semakin kaburnya pedoman moral.

Ciri-ciri tersebut sebagian besar telah tampak pada peserta didik di berbagai jenjang sekolah. Upaya yang serius dan terpadu dalam menanamkan karakter pada peserta didik, sebagai salah satu solusi yang perlu dilakukan di sekolah. Lickona (Ajat Sudrajat, 2011, p49) menegaskan pentingnya pendidikan karakter di sekolah, karena(1) pendidikan karakter merupakan cara terbaik untuk menjamin peserta didik memiliki kepribadian, (2) pendidikan karakter merupakan cara untuk meningkatkan prestasi akademik, (3) pendidikan karakter diterapkan di sekolah karena sebagian peserta didik tidak dapat membentuk karakter di tempat lain, (4) pendidikan karakter merupakan cara peserta didik untuk dapat hidup dalam masyarakat yang beragam, (5) pendidikan karakter merupakan cara untuk memberantas akar masalah yang berkaitan dengan problem moral, seperti ketidaksopanan, ketidakjujuran, kekerasan, pelanggaran kegiatan seksual, dan etos kerja (belajar) yang rendah. (6) pendidikan karakter merupakan persiapan untuk menyongsong perilaku di tempat kerja, dan (7) pendidikan karakter dengan menanamkan nilai-nilai budaya merupakan bagian dari kerja peradaban.

Berdasarkan pengamatan awal di SMPN 3 Banguntapan, ditemukan peserta didik tidak membalas senyum yang diberikan kepada mereka. Ketika guru mejelaskan pelajaran sebagian dari mereka bersikap acuh.Mereka juga belum mempunyai keterampilan dalam berkomunikasi utamanya dalam menyampaikan gagasan dan sanggahan.Juga sebagian mereka belum ada rasa penyesalan ketika mendapat nilai rendah. Menurut guru, rasa tanggung jawab dan kejujuran peserta didik juga rendah dalam hal mengumpulkan tugas.

Penilaian dilakukan oleh MKKS, sehingga guru tidak leluasa mengembangkan pembelajaran. Pembelajaran IPS belum dilaksanakan secara terpadu, membuat peserta didik tidak mampu melihat hubungan antar berbagai konsep yang dipelajari, sehingga mereka juga belum mampu mengaplikasikan dalam menyelesaikan permasalahan sehari-hari.

Melihat kenyataan-kenyataan tersebut, harus ada upaya mengatasinya, baik yang terjadi pada peserta didik maupun guru. Peneliti menawarkan pembelajaran IPS Terpadu model nested untuk meningkatkan karakter peserta didik. Pembelajaran IPS terpadu model nested dimaksudkan untuk membantu peserta didik mempelajari konsep IPS secara terpadu sehingga peningkatan ranah kognitif, afektif, dan psikomotor dalam pembelajaran dapat terjadi.

Upaya untuk meningkatkan karakter siswa, yaitu dengan pendekatan komprehensif. Menurut Zuchdi (2010, p46) "pendekatan komprehensif meliputi inkulkasi (inculcation), keteladanan (modelling), fasilitasi (facilitation), dan pengembangan keterampilan (skill building)".

Dari empat langkah pendekatankomprehensif tersebut, Zuchdi (2010, pp.46-50) mengungkapkan:

Pertama inkulkasi, meliputi: (a) kepercayaan yang diberikan kepada peserta didik 
disertai dengan alasan, (b) memperlakukan peserta didik secara adil, (c) memberikan penghargaan, (d) keragu-raguan atau tidak percaya disertai dengan alasan dan penuh rasa hormat, (e) tidak sepenuhnya mengontrol lingkungan untuk menyampaikan atau meningkatkan nilainilai yang dikehendaki, (f) menciptakan pengalaman sosial dan emosional tidak secara ekstrem, (g) aturan, penghargaan, dan konskuensi dengan alasan, (h) membuka komunikasi kepada pihakpihak yang tidak setuju, (i) memberikan kebebasan, dan apabila sampai tidak dapat diterima diberikan arahan.

Kedua pemodelan atau pemberian teladan dilakukan dengan dua syarat: 1) guru berperan sebagai model yang baik, artinya apa yang dilakukan guru baik perkataan, ucapan, dan tingkahlaku dicontoh oleh peserta didik, dan 2) cara guru dalam menyelesaikan masalah, menghargai pendapat, mengkritik secara santun, merupakan perilaku alami yang dicontoh peserta didik.

Ketiga fasilitasi yaitu memberikan kesempatan kepada peserta didik. Artinya peserta didik dijadikan sebagai subjek dalam bertutur kata, bersikap, dan bertingkah laku.

Keempat pengembangan keterampilan akademik dan sosial, meliputi: berfikir kritis, berfikir kreatif, berkomunikasi secara jelas, menyimak, bertindak asertif (wajar), dan menemukan resolusi konflik. Guru seyogyanya dalam melakukan proses pembelajaran mengembangkan keempat langkah tersebut, sehingga tujuan pembelajaran dapat dicapai.

Strategi pengembangan karakter menurut Winarni, (2013, pp.96-106), ada tiga tahapan yang dilakukan, yakni: identifikasi nilai, pembelajaran nilai, dan memberikan kesempatan untuk menerapkan nilai tersebut. Pertama, identifikasi nilai. Kegiatan mengidentifikasi nilai perlu dilakukan, karena ada kalanya berbeda dipahami di masyarakat, tergantung dengan kultur setempat. Oleh karena itu perlu mengidentifikasi nilai-nilai yang bersifat universal yang ditanamkan dan dikembangkan di sekolah. Kedua, pembelajaran nilai. Pada tahap ini guru menanamkan nilai kepada peserta didik dengan langkah-langkah sebagai berikut: Guru perlu menciptakan lingkungan kelas yang memungkinkan nilai-nilai moral yang ditumbuhkembangkan dapat diterapkan. Tahap selanjutnya guru perlu menunjukkan ketaladanan kepada para siswanya di kelas, mulai dari cara berpakaian, berbicara, bersikap, dan bertingkahlaku. Langkah selanjutnya yang dilakukan bersama antara guru dengan peserta didik, yaitu dengan menjelaskan dan mendiskusikan pentingnya perilaku bermoral. Hasil diskusi tersebut lalu disusun aturan main di dalam kelas atau proses pembelajaran yang dituangkan dalam kode etik. Kode etik yang disusun tersebut ditulis dan ditempelkan di dinding kelas, sehingga masing-masing dapat mengingat dan membacanya untuk dijadikan kontrol bersama.Selanjutnya diharapkan peserta didik terus mengembangkan nilai-nilai moral tersebut. Ketiga, penerapan nilai. Pada tahap ini yang terpenting adanya konsistensi antara nilai-nilai yang telah dipilih dengan apa yang diterapkan. Langkah penerapan nilai-nilai ini, yaitu dengan membentuk kebiasaan rutin di kelas dan dengan memberikan reward bagi siapa yang berperilaku bermoral, seperti tanda bintang pada pramuka atau dengan kata-kata.

Pengintegrasian pendidikan karakter menurut Winarni, (2013, p99), menggunakan pembelajaran terpadu model Nested (tersarang), dimaksudkan untuk memudahkan guru menerapkan di sekolah dengan pendekatan komprehensif, dan terintegrasi dalam kelas. Komprehensif artinya menyeluruh baik tujuan, proses, mapun penilaian mengacu pada pencapaian target karakter. Terintegrasi yaitu dilakukan oleh segenap komponen di sekolah, lebih-lebih oleh guru di kelas, menyangkut penyusunan silabus, RPP, bahan ajar, media, penilaian, dan tindak lanjut.

Winarni, (2013, p102) menyebutkan bahwa: penyusunan silabus perlu menambahkan komponen karakter di antara kolom KD dan kolom materi pembelajaran, pada kegiatan pembelajaran dimodifikasi kegiatan pengembangan karakter, pada indikator dimodifikasi indikator yang terkait dengan pengembangan karakter, dan pada penilaian dimodifikasi teknik yang dapat mengukur perkembangan karakter.

Penyusunan RPP memberi petunjuk pada guru dalam menciptakan wawasan pengembangan karakter.Untuk itu diperlukan adaptasi pencapaian tujuan yang mengarah pada pembentukan karakter, kegiatan pembelajaran juga 
mengarah pada pengembangan karakter, pengembangan indikator mengarah pada pengembangan karakter, dan pada penilaian ada teknik yang dapat mengukur perkembangan karakter.Juga bahan ajar diselipkan materi yang dapat mengarah pada pencapaian karakter.Untuk itu adaptasi yang mungkin dilaksanakan oleh guru dengan menambah bahan ajar atau mengubah kegiatan belajar pada buku pegangan guru.

Nilai peserta didik menggambarkan perkembangan karakter, yang dinyatakan secara kualitatif.Nilai tersebut dijadikan dasar untuk memberikan pembinaan bagi peserta didik. Pengembangan Pendidikan Budaya dan Karakter Bangsa (Puskurbuk, 2010, p23) mengemukakan sebutan nilai perkembangan karakter, yaitu:

$$
\begin{aligned}
& \text { MK/A }=\text { Membudaya. } \\
& \text { MB/B }=\text { Mulai Berkembang. } \\
& \text { MT/C }=\text { Mulai Terlihat. } \\
& \text { BT/D }=\text { Belum Terlihat. }
\end{aligned}
$$

Pengintegrasian pendidikan karakter dalam pembelajaran menurut Marzuki (2012, pp.7-11), diupayakan inovasi pendidikan karakter, yaitu: (1) pengintegrasian ke dalam semua mata pelajaran, (2) pengintegrasian ke dalam pelaksanaan kegiatanpembinaan kesiswaan, dan (3) dilaksanakan melalui kegiatan pengelolaan semua urusan sekolah.

Dalam proses pembelajaran dilaksanakan mulai dari tahap perencanaan, pelaksanaan, hingga evaluasi pembelajaran pada semua mata pelajaran. Tahap perencanaan meliputi: Analisis $\mathrm{KI} / \mathrm{KD}$, pengembangan silabus, penyusunan RPP, dan penyiapan bahan ajar. Analisis KI/KD dilakukan untuk mengidentifikasi nilai-nilai karakter yang secara substansi dapat diintegrasikan pada $\mathrm{KI} / \mathrm{KD}$ yang bersangkutan.Pengembangan silabus dapat dilakukan dengan merevisi silabus yang telah dikembangkan dengan menambah kolom karakter tepat di sebelah kanan kolom kompetensi dasar. Pada kolom tersebut diisi nilai-nilai karakter yang hendak diintegrasikan dalam pembelajaran. Setelah itu kegiatan pembelajaran, indikator pencapaian, teknik penilaian, diadaptasi ulang dengan penyesuaian karakter yang dikembangkan.

Penyusunan RPP dilakukan dengan cara: (1) perumusan tujuan pembelajaran tidak hanya mengembangkan kemampuan kognitif dan psikomotorik, tetapi juga karakter, (2) metode pembelajaran dipilih agar dapat memfasilitasi peserta didik mencapai pengetahuan dan keterampilan yang ditargetkan, juga mengembangkan karakter, (3) kegiatan pembelajaran dalam setiap langkah pembelajaran dapat memfasilitasi peserta didik memperoleh pengetahuan dan keterampilan yang ditargetkan dan mengembangkan karakter, (4) teknik penilaian dilakukan untuk mengukur pencapaian peserta didik dalam kompetensi dan karakter. Di antara teknik-teknik penilaian yang dapat dipakai untuk mengetahui perkembangan karakter adalah observasi, penilaian antar teman, dan penilaian diri sendiri yang dinyatakan secara kualitatif, misalnya: Belum terlihat, mulai terlihat,mulai berkembang, dan membudaya, (5) bahan ajar diadaptasi dengan cara menambah kegiatan pembelajaran yang sekaligus dapat mengembangkan karakter, atau mengubah kegiatan belajar pada buku ajar yang digunakan, juga dapat dilakukan dengan merevisi substansi pembelajarannya.

Penyusunan pembelajaran dirancang langkah-langkah yang memfasilitasi peserta didik aktif dalam proses pembelajaran, agar mereka dapat mempraktikkan nilai-nilai karakter yang ditargetkan. Perilaku guru sepanjang proses pembelajaran harus merupakan model pelaksanaan nilai-nilai bagi peserta didik. Strategi pembelajaran dirumuskan langkah-langkahnya agar mudah disusun dan dapat dipraktikkan dengan baik dan benar.

Pedoman Pengembangan Pendidikan Budaya dan Karakter Bangsa (Puskurbuk, 2011, p6),menjelaskan proses penanaman nilai-nilai karakter, dilakukan secara koheren, tahapannya dengan sosialisasi, pemberdayaan, pembudayaan, dan kerjasama seluruh komponen bangsa dengan pendekatan sistematik dan integrative dengan melibatkan berbagai komponen

Dalam menginternalisasikan karakter ke dalam diri peserta didik, diharapkan mereka mampu mengaplikasikannya dengan sebaikbaiknya dalam kehidupan sehari-hari.Kebiasaan membuang sampah pada tempatnya, antri, tidak menyeberang jalan, tidak parkir sembarangan, tidak merugikan atau menyakiti orang lain, mandiri serta perilaku-perilaku lain yang menunjukkan adanya pemahaman yang baik terhadap 
aturan sosial merupakan hasil dari perkembangan kualitas moral dan mental seseorang yang disebut karakter.

Hasil belajar yang komprehensif adalah kualitas pembelajaran dari segi proses dan hasil belajar. Adapun hasil belajar dapat diperoleh dari hasil kognitif, afektif dan psikomotorik. Pembelajaran sebagai suatu proses melibatkan beberapa unsur antara lain: tujuan pembelajaran, pengalaman belajar, dan hasil belajar.

Mata pelajaran IPS yang disusun secara sistematis, komprehensif, dan terpadu (Sapriya, 2011, p201), dengan tujuan:

1. mengenal konsep-konsep yang berkaitan dengan kehidupan masyarakat dan lingkungannya.

2. memiliki kemampuan dasar untuk berpikir logis dan kritis, rasa ingin tahu, inkuiri, memecahkan masalah, dan keterampilan dalam kehidupan sosial.

3. memiliki komitmen dan kesadaran terhadap nilai-nilai sosial dan kemanusiaan.

4. memiliki kemampuan berkomunikasi, bekerja sama dan berkompetisi dalam msyarakat yang majemuk, di tingkat lokal, nasional, dan global.

Dalam Lampiran Permendiknas Nomor 22 Tahun 2006 tentang Standar Isi (BSNP, 2006, p13) menyatakan bahwa substansi mata pelajaran IPS pada SMP/MTs merupakan IPS Terpadu, maka pada pelaksanaannya pembelajaran terpadu melibatkan peserta didik memperoleh pengalaman langsung, sehingga dapat menambah kekuatan untuk menerima, menyimpan, dan memproduksi kesan-kesan tentang hal-hal yang dipelajari.Dengan demikian, peserta didik terlatih untukmenemukansendiriberbagai konsep yang dipelajari.Model pembelajaran terpadu menurut Ruhimat, (2007, pp.6-9), yaitu: (1) model integrasi berdasarkan topik, merupakan keterpaduan yang dilakukan berdasarkan topik yang terkait antara materi yang ada dalam pelajaran IPS, (2) model integrasi berdasarkan potensi utama, yaitu mengembangkan topik yang didasarkan pada potensi utama yang ada di wilayah setempat (3) model integrasi berdasarkan permasalahan, yaitu pembelajaran terpadu berdasarkan permasalahan yang ada.
Pembelajaran terpadu memiliki karakteristik,yaitu: (1) berpusat pada anak, (2) memberi pengalaman langsung, (3) pemisahan antara mata pelajaran tidak begitu jelas, (4) menyajikan konsep berbagai mata pelajaran dalamprosespembelajaran, (5) bersifat luwes, (6) hasil pembelajaran berkembang sesuai dengan minat dan kebutuhan anak, (7) holistik, artinya suatu peristiwa yang menjadi pusat perhatian dalam pembelajaran terpadu di amati dan di kaji dari beberapa mata pelajaran sekaligus, (8) bermakna, artinya pengkajian suatu fenomena dari berbagai macam aspek memungkinkan terbentuknya semacam jalinan skema yang dimiliki peserta didik, (9) otentik,informasipengetahuan yang diperoleh sifatnya menjadi otentik, dan (10) aktif, artinya peserta didik perlu terlibat langsung dalam proses pembelajaran (Model Bahan Ajar, Puskurbuk, 2008, pp.7-9).

Fogarty (Resmini, 2007, pp.2-5) terdapat sepuluh model dalam pembelajaran terpadu. Kesepuluh model tersebut adalah: (1) fragmented, pada pembelajaran tradisional misahkan disiplin ilmu, seperti matematika, sains bahasa dan studi sosial, humaniora dan seni, (2) connected, bahwa butir-butir pembelajaran dapat dipayungkan pada induk mata pelajaran tertentu, (3) nested, pemanduan berbagai bentuk penguasaan konsep keterampilan melalui sebuah kegiatan pembelajaran, (4) sequenced, pemanduan topiktopik antar mata pembelajaran yang berbeda secara parallel, (5) shared, bentuk pemanduan pembelajaran akibat adanya overlapping konsep atau ide pada dua mata pembelajaran / lebih, (6) webbed, pembelajaran yang dipergunakan untuk mengajarkan tema tertentu yang berkecenderungan dapat disampaikan melalui beberapa bidang studi lain, (7) threaded, pendekatan pembelajaran yang ditempuh dengan cara mengembangkan gagasan pokok yang merupakan benang merah (galur) yang berasal dari konsep yang terdapat dalam berbagai disiplin ilmu, (8) integrated, sejumlah topik dari mata pembelajaran yang berbeda, tetapi esensinya sama dalam sebuah topik tertentu, (9) immersed, dirancang untuk membantu siswa dalam menyaring dan memadukan berbagai pengalaman dan pengetahuan dihubungkan dengan medan pemakaiannya, dan (10) networked. pemanduan pembelajaran yang mengandalkan kemungkinan pengubahan konsepsi. 
Dari kesepuluh model tersebut, Fogarty (Trianto, 2010, p39) mengelompokkan ke dalam tiga model yakni: (1) model pengintegrasian kurikulum di dalam satu disiplin ilmu (interdisiplin ilmu), yaitu model fragmented, connected, dan nested, (2)model pengintegrasian kurikulum beberapa disiplin ilmu (antar disiplin ilmu), yaitu model sequenced, shared, webbed, hreded dan integrated, (3) model pengintegrasian di dalam dan beberapa disiplin ilmu ( inter dan antar disiplin ilmu), yaitu model immersed dan networked.

Model nested (tersarang) menurut Trianto (2010, p45), yaitu "pengintegrasian kurikulum di dalam satu disiplin ilmu secara khusus meletakkan fokus pengintegrasian pada sejumlah keterampilan belajar yang ingin dilatihkan". Untuk mata pelajaran sosial, dapat memadukan keterampilan berpikir dan keterampilan sosial.

Tabel 1. Unsur Keterampilan Berpikir, Sosial, dan Mengorganisasi

\begin{tabular}{|c|c|}
\hline $\begin{array}{c}\text { Keterampilan } \\
\text { Berpikir }\end{array}$ & $\begin{array}{l}\text { Keterampilan } \\
\text { Sosial } \\
\end{array}$ \\
\hline 1. Memprediksi & $\begin{array}{l}\text { 1. Memperhatikan } \\
\text { pendapat orang }\end{array}$ \\
\hline 2. Menyimpulkan & 2. Mengklasifikasi \\
\hline 3. Membuat hipotesis & 3. Menjelaskan \\
\hline 4. Membandingkan & 4. Memberanikan diri \\
\hline 5. Mengklasifikasi & $\begin{array}{l}\text { 5. Menerima pendapat } \\
\text { orang }\end{array}$ \\
\hline 6. Mengeneralisasi & $\begin{array}{l}\text { 6. Menolak pendapat } \\
\text { orang }\end{array}$ \\
\hline 7. Membuat prioritas & 7. Menyepakati \\
\hline 8. mengevaluasi & 8. Meringkaskan \\
\hline
\end{tabular}

Sumber: Trianto (2010, p65)

Model nested atau tersarang adalah pengintegrasian desain pembelajaran dimaksudkan untuk memperkaya guru agar lebih terampil dalam mengembangkan konsep sehingga pembelajaran lebih bermakna. Guru dapat memanfaatkan situasi dan kondisi apapun untuk mencapai tujuan pembelajaran. Model nested memerlukan perencanaan yang tepat dalam mencapai sasaran, dengan memanfaatkan sumber daya yang ada termasuk alam sekitar. Model nested dapat digunakan selain menanamkan konsep suatu materi juga aspek keterampilan lainnya menjadi satu kesatuan.
Kompetensi yang ingin dicapai oleh mata pelajaran IPS bagi peserta didik menurut Nursid Sumaatmaja (Sugiharsono, 2009, p4) yaitu untuk mengembangkan diri agar peserta didik peka terhadap masalah sosial yang terjadi di masyarakat, memiliki sikap mental positif terhadap perbaikan segala ketimpangan yang terjadi, dan terampil mengatasi setiap masalah sosial yang terjadi sehari-hari baik yang menimpa dirinya sendiri maupun yang menimpa kehidupan masyarakat sekitarnya. Implementasi kurikulum ini memerlukan berbagai studi yang mengarah pada peningkatan efisiensi dan efektivitas dalam pembelajaran IPS.peserta didik dapat memperoleh pengalaman langsung, sehingga dapat menambah kekuatan untuk menerima, menyimpan, dan memproduksi kesan-kesan tentang hal-hal yang dipelajarinya. Dengan demikian, peserta didik terlatih untuk dapat menemukan sendiri berbagai konsep yang dipelajari secara holistik, bermakna, otentik, dan aktif.

Bintek, Dirjen Mandikdasmen (Sugiharsono, 2009, pp.4-5), Model pembelajaran IPS terpadu merupakan salah satu model implementasi kurikulum yang dianjurkan untuk diaplikasikan pada semua jenjang pendidikan, mulai tingkat Sekolah Dasar sampai Sekolah Menengah Atas. Di samping itu pembelajaran terpadu merupakan pendekatan pembelajaran yang memungkinkan peserta didik baik secara individual maupun kelompok aktif mencari, menggali, dan menemukan konsep serta prinsip secara holistik dan otentik.Cara pengemasan pengalaman belajar yang dirancang guru sangat berpengaruh terhadap kebermaknaan pengalaman bagi para peserta didik. Pengalaman belajar lebih menunjukkan kaitan unsur-unsur konseptual menjadikan proses pembelajaran lebih efektif. Kaitan konseptual yang dipelajari dengan sisi bidang kajian yang relevan akan membentuk skema, sehingga peserta didik memperoleh keutuhan dan kebulatan pengetahuan.

Dalam kenyataannya, pembelajaran IPS di SMP sebagian besar masih dilaksanakan secara terpisah dengan masing-masing bidang diajarkan satu guru, atau satu guru mengajarkan IPS tapi dengan bahan yang dipisah-pisah.Hal tersebut tentu saja menghambat ketercapaian tujuan IPS itu sendiri yang dirumuskan atas dasar realitas dan fenomena sosial yang mewujudkan satu 
pendekatan interdisipliner dari aspek dan cabangcabang ilmu sosial.

Sugiharsono (2009, p5), penyebab pembelajaran IPS belum dilakukan antara lain: (1) kurikulum IPS tidak menggambarkan satu kesatuan yang terintegrasi, melainkan masih terpisah-pisah antarbidang ilmu-ilmu sosial, (2) latar belakang guru yang mengajar merupakan guru disiplin ilmu, sangat sulit untuk melakukan pembelajaran yang memadukan antardisiplin ilmu tersebut, (3) terdapat kesulitan dalam pembagian tugas dan waktu pada masing-masing guru IPS secara terpadu, dan (4) meskipun pembelajaran terpadu bukan merupakan hal yang baru namun bagi guru dianggap hal yang baru.

Kelebihan pembelajaran terpadu model Nested yaitu: Trianto (2010, p46), mengungkapkan kelebihan dan kekurangan pembelajaran terpadu model nested, yaitu:

1. Guru dapat memadukan beberapa keterampilan sekaligus dalam pembelajaran satu mata pelajaran.

2. Pembelajaran semakin berkembang dan diperkaya dengan menjaring dan mengumpulkan sejumlah tujuan dalam pengalaman belajar siswa.

3. Pembelajaran dapat mencakup banyak dimensi dengan fokus pada isi pelajaran, strategi, keterampilan, dan ide lain yang ditemukan.

4. Memberikan perhatian pada berbagai bidang penting dalam satu saat sehingga tidak memerlukan penambahan waktu sehingga guru dapat memadukan kurikulum secara luas.

Kekurangan pembelajaran terpadu model Nested Perencanakan pembelajaran tidak matang, akan berdampak pada peserta didik karena prioritas pembelajaran menjadi kabur karena peserta didik diarahkan melakukan beberapa tugas belajar sekaligus.

Sugiharsono (2009, p11), menyebutkan tujuan pegembangan pembelajaran IPS Terpadu, sebagai berikut:

1. memberikan wawasan dan pemahaman tentang pembelajaran terpadu, khususnya pada pembelajaran IPS;

2. membimbing guru agar memiliki kemampuan melaksanakan pembelajaran terpadu antardisiplin ilmu-ilmu sosial pada mata pelajaran IPS;

3. memberikan keterampilan kepada guru untuk dapat menyusun rencana pembelajaran dan penilaian secara terpadu dalam pembelajaran IPS;

4. memberikan wawasan, pengetahuan, dan pemahaman bagi pihak terkait, sehingga mereka dapat memberikan dukungan terhadap kelancaran dan ketepatan pelaksanaan pembelajaran terpadu; dan

Penerapan model nested, diawali dengan menentukan tema yang ingin dicapai dalam satu mata pelajaran dan jenis keterampilan yang dipadukan, dengan menggunakan pokok bahasan/ sub pokok bahasan untuk menyarang keterampilan, konsep dan perilaku yang diharapkan tercapai. Kemudian menentukan jenis keterampilan yang akan dikembangkan untuk mencapai tujuan pembelajaran. Guru menyusun langkah-langkah pembelajaran secara sistematis agar tidak membingungkan peserta didik.

Sintaks pembelajaran terpadu model nested (Trianto, 2010, pp.199-208), yaitu: tahap perencanaan, tahap pelaksanaan, dan tahap evaluasi.Tahap perencanaan, meliputi: (a) pemetaan kompetensi dasar, (b) penentuan topik/tema, (c) perumusan kompetensi dasar ke dalam indikator sesuai topik/tema, (d) pengembangan silabus, dan (e) penyusunan rencana pembelajaran.

Tahap pelaksana pembelajaran, meliputi: (a) kegiatan pendahuluan, di antaranya: Memeriksa kehadiran peserta didik, menumbuhkan kesiapan belajar peserta didik, menciptakan suasana belajar yang demokratis, membangkitkan motivasi belajar peserta didik, membangkitkan perhatian peserta didik, dan melaksanakan kegiatan apersepsi, dan penilaian awal, (b) kegiatan inti. Lampiran Permendiknas Nomor 41 tahun 2007 tentang standar proses, menyebutkan langkah dalam kegiatan inti, yaitu: Eksplorasi, elaborasi, dan konfirmasi.

Kegiatan penutup dan tindak lanjut, meliputi: (a) bersama-sama dengan peserta didik membuat simpulan, (b) melakukan penilaian secara konsisten dan terprogram, (c) memberikan umpan balik terhadap proses dan hasil belajar, (d) merencanakan kegiatan remedi, pengayaan, layanan konseling, dan memberikan tugas, dan (e) 
menyampaikan rencana pembelajaran pada pertemuan berikutnya.

Berdasarkan kajian penelitian terdahulu yang relevan baik penelitian penanaman karakter maupun penelitian pembelajaran IPS Terpadu, diperlukan pendekatan yang konprehensif agar pembelajaran lebih berkualitas dari segi proses dan hasil. Komprehensif dimaksudkan baik dari segi tujuan pembelajaran, pelaksana pembelajaran, dan dilakukan dengan perencanaan yang matang.Berdasarkan hasil kajian terdahulu, penelitian ini diharapkan mampu menunjukkan hasil yang lebih bermakna dengan ditandai peningkatan karakter peserta didik yang membudaya di kelas, yang dapat berimbas pada sekolah, rumah tangga, masyarakat di sekitar peserta didik, dan bangsa Indonesia.

Strategi yang dilakukan dalam peningkatan karakter peserta didik melalui pembelajaran IPS Terpadu model nested, dilakukan mulai dari perencanaan pembelajaran yang meliputi penyususnan silabus, penyususnan rencana pembelajaran, dan evaluasi pembelajaran.

\section{Pertanyaan Penelitian}

1. Seberapa besar peningkatan karakter melalui pembelajaran IPS terpadu model nested?

2. Seberapa besar peningkatan keterampilan peserta didik setelah penerapan pembelajaran IPS Terpadu model nested?

3. Seberapa besar peningkatan hasil belajar peserta didik setelah penerapan pembelajaran IPS Terpadu model nested?

\section{Metode Penelitian}

Metode yang digunakan dalam penelitian ini adalah metode penelitian tindakan kelas Pemilihan jenis penelitian ini didasarkan pada permasalahan yang terjadi di dalam kelas. Oleh karena itu, perlu dilakukan suatu penelitian tindakan kelas secara kolaboratif dan partisipatif.

Penelitian tindakan kelas ini melalui pembelajaran IPS Terpadu model nested (tersarang), yaitu pengintegrasian kurikulum dalam satu disiplin ilmu, fokus pengintegrasian pada keterampilan belajar. Keterampilan yang dimaksudkan adalah keterampilan berpikir dan keterampilan sosial. Penelitian ini menggunakan desain siklus yang terdiri atas empat tahap yaitu: perencanaan, tindakan, observasi dan refleksi (plan, act, observe, and reflect).

Penelitian ini dilaksanakan dalam tiga siklus dan pada setiap siklus terdiri atas satu atau dua kali pertemuan dengan alokasi waktu 2 x 40 menit. Perencanaan berdasarkan hasil pengamatan awal terhadap situasi kelas. Dari sini akan mendapatkan gambaran umum tentang masalah yang ada. Lalu peneliti bersama kolaborator melakukan pengamatan terhadap proses pembelajaran di kelas, dengan perhatian tercurah kepada perilaku guru terkait penanaman karakter, dan perilaku peserta didik selama proses pembelajaran.

Waktu penelitian dilaksanakanpada semester gasal tahun pembelajaran 2013/2014 bulan September-Nopember 2013. Subjek penelitian ini peserta didik kelas VII G SMP Negeri 3 Banguntapan Bantul. Pertimbangan pemilihan objek penelitian ini, bahwa kompetensi yang diharapkan dicapai oleh peserta didik dengan materi konektivitas antar ruang dan waktu dan interaksi manusia dan lingkungan.Pemilihan kelas VII G, karena didasarkan hasil observasi dan informasi dari guru bahwa nilai-nilai karakter, keterampilan, dan rerata hasil belajar masih rendah.

Instrumen observasi terdiri atas lembar observasi, adalah daftar pengamatan mengenai karakter peserta didik selama proses pembelajaran berlangsung di kelas. Observasi dilakukan untuk mengamati nilai karakter peserta didik pada indikator:

1. Religius, yaitu: (a) peserta didik berdoa dalam pembelajaran, (b) memberi salam saat pergantian jam pembelajaran, (c) selalu mengucapkan terima kasih, maaf, permisi dan tolong, dan (d) bicara dan bertindak dengan sopan santun.

2. Jujur, yaitu: (a) peserta didiktidak mencontek dalam mengerjakan tugas, (b) menyediakan kotak saran dan pengaduan, dan (c) menyediakan tempat temuan barang.

3. Disiplin, yaitu: (a) mencatat kehadiran di kelas, (b) kumpulan surat izin dan keterangan sakit, dan (c) kerapian diri dan berpakaian.

4. Peduli lingkungan, yaitu: (a) membuang sampah pada tempatnya, (b) mengambil 
sampah di sekitar kelas, (c) piket kelas dilakukan semua anggota piket, dan (d) menata bangku dan kursi.

Observasi dilakukan juga untuk mengamati aktivitas diskusi dan presentasi kelompok selama proses pembelajaran. Tes digunakan untuk mengetahui perkembangan atau peningkatan hasil belajar peserta didik yang dilakukan secara tertulis pada setiap akhir siklus tindakan.Instrumen yang digunakaan adalah soal tes hasil belajar.

Dokumentasi merupakan kegiatan yang dilakukan peneliti bersama kolaborator untuk mendapatkan dan pengumpulan data tertulis maupun tidak tertulis.Instrumen yang digunakan adalah daftar cek (check list). Dokumentasi untuk mendapatkan bukti adanya kegiatan selama proses tindakan. Dokumentasi tertulis antara lain hasil belajar peserta didik, transkrip wawancara. Dokumentasi yang tidak tertulis berupa gambar atau foto pada waktu kegiatan penelitian berlangsung.

Teknik analisis data yang digunakan dalam penelitian ini adalah deskriptif komparatif dengan menggunakan persentase. Nilai persentase pada hasil belajar pada ranah psikomotor, dan kognitif digunakan untuk membandingkan kemajuan yang diperoleh dari satu siklus ke siklus berikutnya.

Kriteria keberhasilan tindakan ditentukan dari analisis data kuantitatif dengan mengacu teknik analisis data yang telah disajikan. Kriteria keberhasilan tindakan dalam penelitian ini ditentukan sebagai berikut: (a) Berdasarkan hasil analisisperhitungan nilai karakter, penelitian ini dihentikan jika rerata nilai karakter peserta didik berdasarkan observasi mencapai nilai $\geq 76$. (b) Berdasarkan hasil analisis perhitungan nilai keterampilan, maka penelitian ini akan dihentikan jika rerata keterampilan peserta didik telah mencapai nilai $\geq 70$. (c) Kriteria keberhasilan tindakan ditetapkan yaitu:daya serap 70, ketuntasan belajar kelas mencapai $85 \%$ peserta didik telah mencapai ketuntasan individu.

\section{Hasil Penelitian dan Pembahasan}

Penelitian ini penerapan pembelajaran model nested yang dilaksanakan selama tiga siklus.
Hasil siklus I

Tabel 2. Kategorisasi Nilai Karakter Berdasarkan Observasi Siklus I

\begin{tabular}{lll}
\hline \multicolumn{1}{c}{ Karakter } & Nilai & $\begin{array}{c}\text { Perkembangan } \\
\text { Nilai Karakter }\end{array}$ \\
\hline Religius & $50 \%$ & Mulai Terlihat \\
Jujur & $40 \%$ & Mulai Terlihat \\
Disiplin & $80 \%$ & Membudaya \\
Peduli Lingkungan & $70 \%$ & Mulai Berkembang \\
Rerata & $60 \%$ & Mulai Terlihat \\
\hline
\end{tabular}

Tabel 7 . Distribusi Nilai Keterampilan Peserta Didik Siklus I

\begin{tabular}{lcc}
\hline \multirow{2}{*}{ Keterampilan } & Nilai & \\
\cline { 2 - 2 } & Rerata & \\
\hline Diskusi & 60,77 & Kurang \\
Presentasi & 51,54 & Kurang \\
Rerata & 56,15 & Kurang \\
\hline
\end{tabular}

Tabel 4. Distribusi Nilai Tes Peserta Didik Siklus I

\begin{tabular}{cll}
\hline No & Uraian & Nilai \\
\hline 1 & Tertinggi & 90 \\
2 & Terendah & 35 \\
3 & Rerata & 69,60 \\
4 & Persentase Ketuntasan & $52 \%$ \\
\hline
\end{tabular}

Tindakan yang dilakukan mengikuti sintaks pembelajaran model nested, yaitu: tahap perencanaan, tahap pelaksanaan, dan tahap evaluasi. Tahap perencanaan, meliputi: Pemetaan kompetensi dasar, yaitu memahami aspek keruangan dan konektivitas antar ruang dan waktu dalam lingkup regional serta perubahan dan keberlanjutan kehidupan manusia (ekonomi, sosial, budaya, pendidikan dan politik). Penentuan topik/ tema, yaitu konektivitas antar ruang dan waktu. Perumusan kompetensi dasar dalam indikator sesuai topik.Pengembangan silabus. Penyusunan rencana pembelajaran.

Proses pembelajaran yaitu: Pendahuluan, meliputi: memberi salam sambil menatap peserta didik dengan penuh semangat, guru melakukan presensi, guru mengingatkan peserta didik untuk menyiapkan alat tulis, guru menciptakan suasana belajar yang demokratis dengan merespon tanggapan peserta didik, guru memberi penguatan 
dalam respon yang diberikan, guru melakukan apersepsi terhadap pembelajaran minggu lalu. Kegiatan inti, meliputi: menayangkan video banjir di Jakarta 2012, kemudian peserta didik diajak berpikir kritis dengan mengajukan pertanyaan "Adakah keterkaitan antara ruang yang satu dan ruang lainnya? peserta didik berdiskusi keterkaitan jenis lingkungan, diarahkan untuk mempresentasikan hasil diskusi tentang unsur-unsur keruangan dan konektivitas antar jenis- jenis lingkungan, guru menanamkan nilai-nilai karakter religius, jujur, disiplin, dan peduli lingkungan, guru bersama peserta didik menyimpulkan materi dalam kegiatan pembelajaran.

Kegiatan penutup. Guru menjelaskan keterkaitan nilai-nilai karakter pada materi konektivitas antar ruang dan waktu, peserta didik dan guru bersama-sama membuat simpulan dan berdoa menurut agama dan kepercayaan masing-masing.

Penerapan pembelajaran model nested, menunjukkan peningkatan karakter peserta didik pertemuan pertama $43,5 \%$ menjadi $73,1 \%$ pada pertemuan kedua, dan rerata sebesar $60 \%$, yakni mulai terlihat. Hasil tersebut diperkuat dari hasil angket sebesar 83,41. Aspek keterampilan diskusi dan presentasi pada pertemuan pertama dan kedua dengan rerata 56,15\%, kategori kurang. Penilaian aspek ketuntasan belajar secara kognisi dengan rerata 69,60 , ketuntasan secara klasikal $52 \%$.

Berdasarkan analisis tersebut, diketahui bahwa peningkatan karakter, keterampilan, dan pencapaian daya serap serta ketuntasan klasikal belum mencapai target, dan dilanjutkan pada siklus II.

Pada siklus I kegiatan inkulkasi, permodelan, fasilitasi, dan pengembangan keterampilan belum sepenuhnya dilakukan oleh guru.Untuk itu diperlukan langkah-langkah sebagai berikut:

1. guru mengomunikasikan kegiatan pembelajaran dengan nilai-nilai karakter kepada peserta didik di kelas,

2. memacu peserta didik untuk lebih berani mengemukakan pendapat dan aktif dalam pembelajaran di kelas,

3. guru memberikan penjelasan tentang materi pembelajaran dan urgensinya dalam kehidupan sehari-hari.
Hasil siklus II

Tabel 5. Kategorisasi Nilai Karakter Berdasarkan Observasi Siklus II

\begin{tabular}{lll}
\hline \multicolumn{1}{c}{ Karakter } & Nilai & $\begin{array}{l}\text { Perkembangan } \\
\text { Nilai Karakter }\end{array}$ \\
\hline Religius & $75 \%$ & Mulai Berkembang \\
Jujur & $40 \%$ & Mulai Terlihat \\
Disiplin & $80 \%$ & Membudaya \\
Peduli Lingkungan & $100 \%$ & Membudaya \\
Rerata & $74 \%$ & Mulai Berkembang \\
\hline
\end{tabular}

Tabel 6. Distribusi Nilai Keterampilan Peserta Didik Siklus II

\begin{tabular}{lcc}
\hline Keterampilan & Rerata Nilai & Kategori \\
\hline Diskusi & 68,46 & Terampil \\
Presentasi & 68,46 & Terampil \\
Rerata & 68,46 & Terampil \\
\hline
\end{tabular}

Tabel 7. Distribusi Nilai Tes Peserta Didik Siklus II

\begin{tabular}{llc}
\hline No & Uraian & Nilai \\
\hline 1 & Tertinggi & 90 \\
2 & Terendah & 60 \\
3 & Rerata & 77,69 \\
4 & Persentase Ketuntasan & $84,82 \%$ \\
\hline
\end{tabular}

Tindakan siklus II, mengikuti sintaks pembelajaran model nested, yaitu: tahap perencanaan, tahap pelaksanaan, dan tahap evaluasi. Tahap perencanaan, meliputi: Pemetaan kompetensi dasar, yaitu memahami pengertian dinamika interaksi manusia dengan lingkungan alam, sosial, budaya, dan ekonomi. Penentuan topik/tema, yaitu interaksi manusia dan lingkungan.

Proses pembelajaran yaitu: memberi salam sambil menatap peserta didik dengan penuh semangat, guru melakukan presensi, guru mengingatkan peserta didik untuk menyiapkan alat tulis, guru menciptakan suasana belajar yang demokratis dengan merespon tanggapan peserta didik, guru memberi penguatan dalam respon yang diberikan, guru melakukan apersepsi terhadap pembelajaran minggu lalu.

Kegiatan inti, meliputi: menyajikan gambar tentang keadaan manusia dan lingkungan yang tidak harmonis. meminta peserta didik mengidentifikasi keempat jenis lingkungan, yakni 
biotik, abiotik, budaya, dan lingkungan social, membuat permainan dengan memakai kartu berwarna. memberikan 14 kartu tersebut kepada tiap kelompok secara acak dan peserta didik mencari pasangan kartu yang mereka miliki. Bagi kelompok yang dapat menemukan pasangan lebih cepat, guru memberikan reward atau point tambahan berupa bintang prestasi. Guru memberikan kesempatan untuk mempresentasikan hasilnya. Guru senantiasa menanamkan nilai-nilai karakter religius, jujur, disiplin, dan peduli lingkungan.

Kegiatan penutup, yaitu: peserta didik diajak membuat kesimpulan dan merenung atas manfaat dari kegiatan pembelajaran, bersama-sama berdoa menurut agama dan kepercayaan, penilaian dilakukan selama aktivitas pembelajaran.

Penerapan pembelajaran model nested, dari hasil observasi mampu menunjukkan peningkatan karakter sebesar $74 \%$, berarti nilai rerata karakter mulai berkembang (MB), dari hasil angket meningkat sebesar 84,70kategori sangat baik (SB). Rerata keterampilan diskusi dan presentasi 68,46 , termasuk kategori baik. rerata ketuntasan belajar 77,5 kategori sangat baik, aspek ketuntasan secara klasikal 84,62\%.

Berdasarkan analisis siklus II, belum mencapai target yang ditetapkan, maka penelitian ini dilanjutkan pada siklus III.Langkah-langkah yang dilakukan sebagai berikut:

(1) lebih memfokuskan pada peserta didik yang belum menunjukkan nilai-nilai karakter.

(2) guru lebih banyak lagi memberikan bimbingan, utamanya dalam proses inkulkasi, permodelan, fasilitasi, dan pengembangan keterampilan akademik dan sosial. Di samping itu mendorong didik yang pasif mengikuti proses pembelajaran.

Hasil siklus III

Tabel 8. Kategorisasi Nilai Karakter Berdasarkan Observasi Siklus III

\begin{tabular}{lcc}
\hline \multicolumn{1}{c}{ Karakter } & Nilai & $\begin{array}{c}\text { Perkembangan } \\
\text { Nilai Karakter }\end{array}$ \\
\hline Religius & $87,50 \%$ & MK \\
Jujur & $66,70 \%$ & MB \\
Disiplin & $80 \%$ & MK \\
Peduli Lingkungan & $100 \%$ & MK \\
Rerata & $83,55 \%$ & MK \\
\hline
\end{tabular}

Tabel 9. Distribusi Nilai Keterampilan Peserta Didik Siklus III

\begin{tabular}{|c|c|c|}
\hline \multirow{2}{*}{ Keterampilan } & Nilai & \multirow{2}{*}{ Kategori } \\
\hline & Rerata & \\
\hline Diskusi & 72,31 & Terampil \\
\hline Presentasi & 70,00 & Terampil \\
\hline Rerata & 71,15 & Terampil \\
\hline
\end{tabular}

Tabel 10. Distribusi Nilai Tes Peserta Didik Siklus II

\begin{tabular}{llc}
\hline No & \multicolumn{1}{c}{ Uraian } & Nilai \\
\hline 1 & Tertinggi & 100 \\
2 & Terendah & 40 \\
3 & Rerata & 74,62 \\
4 & Persentase Ketuntasan & $88,46 \%$ \\
\hline
\end{tabular}

Tindakan yang dilakukan yaitu: kompetensi dasar, memahami pengertian dinamika interaksi manusia dengan lingkungan alam, sosial, budaya, dan ekonomi. Penentuan topik, yaitu saling keterkaitan antar komponen lingkungan.

Kegiatan pendahuluan, meliputi: memberi salam sambil menatap peserta didik dengan penuh semangat, guru melakukan presensi, guru mengingatkan peserta didik untuk menyiapkan alat tulis, guru menciptakan suasana belajar yang demokratis dengan merespon tanggapan peserta didik, guru memberi penguatan dalam respon yang diberikan, guru melakukan apersepsi terhadap pembelajaran minggu lalu.

Kegiatan inti, meliputi: menayangkan gambar contoh bentuk-bentuk saling pengaruh manusia dan lingkungannya. peserta didik diminta komentarnya tentang gambar yang ditampilkan di papan tulis, memberikan konfirmasi keterkaitan antar komponen lingkungan dan contohcontohnya, memberikan reward bintang prestasi kepada peserta didik yang mengemukakan pendapat dengan argumentasi logis, memberikan konfirmasi jika argumentasi peserta didik tidak logis, membagi peserta didik menjadi lima kelompok untuk melakukan diskusi, memberi nama kelompok yang menunjukkan alas an nama tersebut, membagi materi diskusi kelompok, memberikan bimbingan kerja kepada masing-masing kelompok dengan cara mendatangi kelompok tersebut, meminta wakil dari setiap kelompok untuk 
menyajikan hasil diskusinya di depan kelas, peserta didik yang lain diminta menanggapi, memberikan konfirmasi atas hasil diskusi.

Kegiatan penutup, yaitu: bersama peserta didik membuat kesimpulan dan merenung atas manfaat dari kegiatan pembelajaran, berdoa menurut agama dan kepercayaan.

Penerapan pembelajaran model nested, dari hasil observasi mampu menunjukkan peningkatan karakter sebesar $83,55 \%$, berarti nilai rerata karakter membudaya. Rerata keterampilan diskusi dan presentasi 71,15, termasuk kategori terampil. Rerata ketuntasan belajar 74,62 kategori sangat baik, aspek ketuntasan secara klasikal $88,46 \%$.

Analisis siklus III, peningkatan karakter, keterampilan, dan aspek ketuntasan belajar (daya serap dan ketuntasan klasikal) telah memenuhi kriteria keberhasilan tindakan. Dengan demikian, penelitian tindakan ini dihentikan.

\section{Simpulan dan Saran}

Simpulan

Dari hasil penelitian diperoleh kesimpulan: (1) Berdasarkan nilai observasi rerata $60 \%$ di akhir siklus I, meningkat $83,55 \%$ di akhir siklus III. (2) Keterampilan peserta didik (keterampilan berdiskusi dan presentasi) dalam pembelajaran. Rerata nilai 56,15 di akhir siklus I, meningkat 71,15 di akhir siklus III. (3) Hasil belajar peserta didik, daya serap sebesar 69,60 di akhir siklus I, meningkat 72,5 di akhir siklus III. Rerata ketuntasan klasikal sebesar 52\% di akhir siklus I, meningkat $88,5 \%$ di akhir siklus III.

Saran

Pembelajaran IPS Terpadu model nested dapat meningkatkan karakter peserta didik jika nilai-nilai karakter tersebut dilakukan secara konprehensif, meliputi: inkulkasi, keteladanan, fasilitasi, dan pengembangan keterampilan. Guru IPS perlu memahami sintaks pembelajaran model nested, untuk memudahkan guru dalam memadukan pembelajaran IPS. Juga memudahkan guru dalam melatih keterampilan peserta didik.Pembelajaran terpadu sulit dilakukan oleh guru tunggal, artinya perlu kolaborasi guru. Oleh karena itu dapat mengakui perhitungan jam pembelajaran dan angka kredit bagi guru yang berkolaborasi dalam pembelajaran. Dinas Pendidikan Kabupaten Lahat hendaknya memberi apresiasi yang tinggi bagi guru yang melakukan penelitian dalam rangka perbaikan pembelajaran.

\section{Daftar Pustaka}

Depdiknas.(2005). Permendiknas. No. 22 Tahun 2005, tentang Standar Isi.

Kemendiknas.(2008). Model bahan ajar. Jakarta: Puskurbuk.

Kemendiknas.(2010). Pengembangan pendidikan budaya dan karakter bangsa. Jakarta: Puskurbuk.

Kemdikbud.(2011). Pedoman Pengembangan Pendidikan Budaya dan Karakter Bangsa. Jakarta: Puskurbuk.

Marzuki, (2012).Pengintegrasian pendidikan karakter dalam pembelajaran di sekolah, Jurnal pendidikan karakter UNY, tahun II, Nomor 1, Tahun 2012.Diambil 19 Juni 2013.Dari www.uny.ac.id.

Resmini, N. (2007). Model-model pembelajaran terpadu, Bandung: Universitas Pendidikan Indonesia. Diambil 19 Februari 2014 dari http.file.upi.edu.

Ruhimat, M. (2007). Panduan pengembangan pembelajaran terpadu IPS (Suplemen materi tot bintek ktsp untuk tim pengembang kurikulum kab/kota. Jakarta: Direktorat PSMP.

Sapriya, (2011).Pendidikan ips, konsep dan pembelajaran.Bandung: $\quad$ PT Remaja Rosdakarya.

Sudrajat, A. (2011). Membangun budaya sekolah berbasis karakter terpuji, Jurnal pendidikan karakter UNY tahun I No. 1, Yogyakarta: UNY Press.Diambil 19 Juni 2013.Dari www.uny.ac.id.

Sugiharsono, (2009).Pengembangan pembelajaran ips terpadu.Yogyakarta: www. uny. ac.id. Diambil 19 Februari 2014. 
Triatmanto, (2010). Tantangan implementasi pendidikan karakter di sekolah,Cakrawala Pendidikan, Th. XXIX, edisi khusus dies natalis UNY.Diambil 19 Juni 2013.Dari www.uny.ac.id.

Winarni, S. (2013). Integrasi pendidikan karakter dalam perkuliahan, Jurnal pendidikan karakter,th. iii no.1.Diambil 19 Juni 2013. Dari www.uny.ac.id.
Zuhdi, D. (2010).Humanisasi pendidikan menemukankembali pendidikan yang manusiawi.Jakarta: Bumi Aksara. 